\title{
The Correlation Between Family Income and Mom's Education with Anemia
}

\author{
$1^{\text {st }}$ Rosi Kurnia Sugiharti \\ Diploma of Midwifery Study Program, \\ Faculty of Health Harapan Bangsa University, \\ Central Java, Indonesia \\ Rossy.kurnia@yahoo.com
}

\begin{abstract}
Puberty is a transition period between childhood and adulthood where growth spurt occurs, and people in this period relatively have not reached the stage of mental and social maturity so they must face conflicting emotional and social pressures. According to WHO, adolescents are when children reach the age of 10-18 years. In adolescence there is one of the problems that mostly appears, that is anemia. Anemia in young women is still a public health problem if the prevalence is more than $15 \%$.In general, the high prevalence of iron nutrition anemia is caused by several factors: chronic blood loss, inadequate iron intake, inadequate absorption, and increased need for iron. Based on preliminary studies obtained from interviews with 25 female midwifery study program students of Harapan Bangsa University Purwokerto, the result showed that $45 \%$ of students experienced severe anemia, 40\% had moderate anemia, and $15 \%$ had mild anemia. The purpose of this study was to determine the factors associated with the incidence of anemia in adolescents. The type of this research was correlation analytic research design with crosssectional approach. Samples were taken using simple random sampling. The results showed that there was a correlation between family income and mom's education with anemia in adolescents.
\end{abstract}

Keywords: family income, mom's education, anemia

\section{INTRODUCTION}

Puberty is a transition period between childhood and adulthood where growth spurt occurs, and the people in this period relatively have not reached the stage of mental and social maturity so they must face conflicting emotional and social pressures. According to WHO, adolescents are when children have reached the age of 10-18 years [1].During this period, psychological and biological changes occur. One of the problems experienced by adolescents is anemia. In general, the high prevalence of iron nutritional anemia is caused by several factors: chronic blood loss, inadequate iron intake, inadequate absorption, and increased need for iron. Adolescent girls suffering from anemia is

\author{
$2^{\text {nd }}$ Etika Dewi Cahyaningrum \\ Diploma of Midwifery Study Program, \\ Faculty of Health Harapan Bangsa University, \\ Central Java, \\ Indonesia tita.etika@gmail.com
}

something understandable because adolescence is a period of growth that requires higher nutrients including iron. Beside that, young women experience menstruation every month, so that they need higher iron, meanwhile the amount of food consumed by them is lower than by the men. Some argue that they want to get a slim body. The abstinence from certain foods and wrong eating habits are also causes of anemia in adolescent girls [2]. Further, young women who suffer from anemia will also decrease their fitness, thus hampering their sports performance and productivity. In addition, adolescence is a period of very rapid growth; hence iron deficiency during this period will result in not achieving optimal height. Based on preliminary studies obtained from interviews with 25 female students of midwifery study program in Harapan Bangsa University of Purwokerto, it was found that $45 \%$ of students experienced severe anemia, $40 \%$ had moderate anemia, and $15 \%$ had mild anemia. From the above problems, the researchers are interested in conducting research on the correlation between family income and mom's education with the anemia in adolescents.

\section{METHODS}

The research model used was analytic correlation research, a research between two variables in a situation or group of subjects. This study used crosssectional design. [3] The population in this study were all students of Diploma of Midwifery Study Program in Harapan Bangsa University as many as 82 female students. Sampling technique used was simple random sampling.. In taking the sample, the researchers used Solvin formula and generated 50 female students. The research was conducted at Harapan Bangsa University of Purwokerto for one month, from May $3^{\text {rd }}$ to June $4^{\text {th }}, 2019$ with a total sample of 50 female students. Data was processed using univariate and bivariate analysis.

III.RESULTS AND DISCUSSION

Table 1 Frequency Distribution of Factors Associated with Anemia in Adolescents

\begin{tabular}{lcc}
\hline Anemia & Frequency & Percentage \\
\hline Anemia & 50 & 50 \\
No anemia & 50 & 50 \\
\hline Total & 100 & 100 \\
\hline Family & Frequency & Percentage \\
\hline
\end{tabular}


Family income has a positive correlation with food expenditure, meaning that the lower the family income, the lower the food expenditure of the subject. Income is directly related to purchasing ability. Families with high incomes have the ability to buy and make it easier to choose food sources such as iron sources like meat, fish, eggs and others to be served. [5]

In addition, the large number of family members at home also affects the food expenditure. The result of study shows that subjects with high food expenditure are influenced by consumptive lifestyles and the large number of family members. Based on the result of the study, it was found that the average food expenditure of the subjects is $48 \%$ of the total family expenditure for one month. [6]

The results of the bivariate analysis between food expenditure and iron intake showed that there was a positive correlation, meaning that the lower the food expenditure the lower the iron intake of subjects. The result of another study in the Netherlands showed there was a correlation between income and vitamin and mineral intake, especially iron. A research in India showed that there was a correlation between income and iron intake, at each level of family income has a prevalence of anemia that is almost the same, this is caused by food expenditure of a family which is spent more to buy food with iron sources derived from vegetable protein, cereals and vegetables.[7]

2. The Correlation between Mom's Education and Anemia

Mom's education is one of the main factors that supports the family's finance and also plays a role in the preparation of family meals, as well as children's nurture and care. [8] For families with a high level of education it will be easier to receive health information, especially in the field of nutrition, so that they can increase their knowledge and be able to apply it in their daily lives.

Mother's education can determine knowledge and skills in deciding the diet for her family which will affect the health status of all family members. Lack of knowledge and skills in choosing the diversity of food ingredients and types of cuisine will affect the intake of family members. [10]

\section{IV.CONCLUSIONS}

There is a correlation between family income and mom's education with the incidence of anemia in adolescents.

\section{REFERENCES}

[1] Andira, Dita. 2012.Seluk Beluk Kesehatan Reproduksi Wanita: Jogjakarta:A Plus Books.

[2] Kusmiran, Eny. 2011. Kesehatan Reproduksi Remaja dan Wanita. Jakarta: Salemba Medika

[3] Notoatmodjo, S. 2010. Metodologi Penelitian Kesehatan. Jakarta: Rineka Cipta. 
kesehatan

[4] Manuaba IBG. 2009. Memahami reproduksi wanita Jakarta: EGC

[5] J. Corwin. 2009. Buku Saku Patofisiologi

[6] Widyastuti, Yani, dkk. 2009.Kesehatan Reproduksi. Yogyakarta: Fitramaya

[7] Morgan \& Hamilton. 2009. Obstetri dan Ginekologi: Panduan Praktik, Edisi 2. Jakarta: EGC

[8] Reeder, Sharon. J, Martin, Leonide L, dan
Griffin, Deborah Koniak. 2011. Keperawatan Maternitas: Kesehatan Wanita, Bayi dan Keluarga, Edisi 8. Jakarta: EGC.

[9] Perry \& Potter. 2009. Fundamental Keperawatan Edisi 7. Jakarta: Salemba Medika 8

[10] H Kozier, Barbara,dkk. 2011. Buku Ajar Fundamental Keperawatan: Konsep, Proses dan Praktik. Jakarta: EGC. 